УДК 39(571.150)

DOI 10.37386/2413-4481-2020-2-106-110

\title{
О.С. Мамонтова
}

\section{ПИМОКАТНОЕ ПРОИЗВОДСТВО В БАРНАУЛЬСКОМ ОКРУГЕ (УЕЗДЕ) В КОНЦЕ XIX - НАЧАЛЕ XX ВВ.}

В статье на основе опубликованных статистических материалов, исследований сибирских ученых и архивных источников освещен процесс развития пимокатного производства Алтая на примере Барнаульского округа (уезда) как одного из крупных пимокатных центров региона в конце XIX - начале XX вв. Приводятся данные о численности пимокатов, количестве мастерских, объемах производства, раскрывается влияние ряда условий на развитие производства.

Ключевые слова: Алтай, Барнаульский округ (уезд), пимокаты, численность, производительность.

\section{O.S. Mamontova}

\section{PIMOKAT MANUFACTURE IN BARNAUL DISTRICT (COUNTY) IN THE LATE $19^{\text {TH }}-$ EARLY $20^{\text {TH }}$ CENTURIES}

\begin{abstract}
Based on published statistical materials, research of Siberian scholars and archival sources, the article describes the development of pimokat (felting) manufacture in the Altai Territory, using the example of Barnaul district (county) as one of the largest pimokat centers of the region in the late $19^{\text {th }}$ - early $20^{\text {th }}$ centuries. It gives the data on the number of pimokats, the amount of workshops, and the production volumes. The article reveals the influence of a number of conditions on the production development.

Key words: Altai Territory, Barnaul District (County), pimokats, number, productivity.
\end{abstract}

В настоящее время тема крестьянских обрабатывающих промыслов русского населения Сибири в XIX - первой половины XX в. сохраняет свою актуальность. На территории всех субъектов Российской Федерации уделяется большое внимание возрождению традиционных ремесел и промыслов, поддержке народных мастеров. Данные процессы невозможны без анализа и изучения исторических, этнографических источников, позволяющих выявить не только технико-технологические традиции, также традиции формообразования, но и их трансформацию под влиянием различных факторов.

Русское население с приходом в Сибирь, в частности на Алтай, развивало и адаптировало свои знания, трудовые навыки к новым природно-климатическим, экономическим, политическим и этнокультурным условиям. В первую очередь это касалось обрабатывающих промыслов, изделия которых были необходимы в быту. Одним из распространенных производств являлась обработка шерсти - пимокатный промысел. На рубеже XIX$\mathrm{XX}$ вв. крупнейшим центром Томской губернии по производству пимов являлся Барнаульский округ (с 1898 г. - Барнаульский уезд).

Пимокатное производство русского населения Алтая до настоящего времени не становилось темой самостоятельного исследования. Для дореволюционной историографии было характерно накопление эмпирического материала, которое началось в середине XIX века, что связано с вниманием государства к деятельности пимокатов. В конце XIX - начале XX в. фактические сведения о состоянии пимокатного промысла на Алтае содержались в работах общего характера, относящихся к социально-экономическому развитию Западной Сибири. В них рассматривался процесс становления частной промышленности Алтая в пореформенный период: история появления первых крупных предприятий, негативное влияние политики Кабинета Его Императорского Величества (далее - ЕИВ) в отношении част- 
ного предпринимательства касательно запретительных мер по установке паровых двигателей и котлов на предприятиях в 1860-1880-х гг. В изданиях приводились данные о географии промысла, численности мастеров, объеме выпускаемой продукции, получаемых доходах, способах реализации. Отмечалось влияние переселенческого движения на его появление и развитие в регионе [1-4]. Так, в работе С.Л. Чудновского приводится высказывание русского старожила по отношению к мастерам-переселенцам из европейской части России: «Мы до них о пимах и не слыхали» [4, с. 147].

В 1970-1980-х гг. пимокатное производство на Алтае затрагивалось в ряде монографий и публикаций сибирских историков в контексте капиталистических отношений в крестьянских промыслах, классового разложения сибирского крестьянства. Наиболее известными являются работы Е.И. Соловьевой, Г.А. Бочановой [5-7]. В 1990-х - начале 2000-х годов пимокаты, как одна из составных частей формировавшейся рабочей среды, были рассмотрены алтайским историком В.А. Скубневским [8]. В публикациях других исследователей рассматривались политика Кабинета ЕИВ по отношению к обрабатывающим промыслам, размещение, состав, объем выпускаемой продукции [9-14]. Пимокатное производство г. Барнаула, как классический вариант возникновения промыслов на новом месте и трансформации его сначала в мануфактурное, а потом и в фабричное, представлено в коллективной монографии алтайских историков М.Ю. Гончарова, А.В. Старцева и В.А. Скубневского [15, с. 98].

В этнографической литературе уделялось внимание бытованию на рубеже веков продукции пимокатного промысла [16; 17, с. 44-46]. В работах этнографов затрагивался вопрос влияния переселенцев на появление и развитие пимокатного производства в Сибири. Так, новосибирский ученый И.В. Октябрьская связывала его становление на Алтае в конце XIX - начале XX в. с переселенческим движением [18]. О.Н. Шелегина, напротив, полагала, что валяная обувь могла быть перенята жителями центральных губерний России у сибиряков-старожилов [19, с. 136-137]. Фиксация технико-технологических традиций пимокатов Алтая отражает трудовые процессы лишь с 1930-1940-х гг.

Ранее автор данной статьи обращался к данной теме в рамках музеефикации традиционных занятий и технологий русского населения Алтая, также при проведении атрибуции, паспортизации и каталогизации музейных коллекций [20-21].
Важным источником для изучения пимокатного дела на Алтае в конце XIX - начале XX в. являются материалы Государственного архива Алтайского края (далее - ГААК), находящиеся в фондах Податных инспекторов 1-го участка Барнаульского, Змеиногорского, Бийского уездов Томской губернской казенной палаты (Ф. 52, 56, 192), Бийского уездного полицейского управления (Ф. 170) и других. В документах фондов представлены данные о географии распространения пимокатного промысла, времени основания, количестве рабочих, производительности, стоимости товара и территориальные рамки его реализации.

Для возникновения и развития любого промысла, в том числе и пимокатного, было необходимо несколько условий: наличие источников сырья, мастеров, рынков сбыта, лояльная политика государства в сфере налогообложения людей, занятых в промысле. Алтай был скотоводческим регионом, что позволяло иметь источники сырья в непосредственной близости от места производства. В конце XIX в. на территории региона получили распространение три породы овец: киргизская с курдюком, обыкновенная русская и длиннохвостая (тонкорунная), завезенная переселенцами в 1860-х гг. из европейской части России. К 1889 г. поголовье овец в Барнаульском округе составляло 364714 голов [1, с. 67, 72]. К концу XIX в. поголовье овец на Алтае выросло до 1 млн голов [15, с. 27]. Стоимость сырья могла либо стимулировать, либо тормозить развитие пимокатного производства. При анкетном обследовании кустарно-ремесленной промышленности в Барнаульском уезде Томским губернским кустарным комитетом в 1915 г. респонденты одним из негативных факторов указывали дороговизну и плохое качество сырья [3, с. 92]. Например, рост цен на шерсть с 13 рублей 50 копеек (15 рублей в 1908 г.) до 16-18 рублей 50 копеек в 1909 г. привел к снижению процента средней прибыльности для производства валяной обуви с 9 до 8 и ее продажи с 7 до 4 [22, л. 11].

Природно-климатические условия поддерживали спрос на продукцию пимокатов. Хотя периодически их влияние было отрицательным. Так, в 1909 г. из-за продолжительной теплой осени и низкого урожая спрос на пимы упал, что привело к замиранию торговли [22, л. 11].

На территории Барнаульского округа (уезда) в конце XIX - начале XX в. были распространены различные формы пимокатного производства: домашнее, ремесленное, кустарное и смешанная мануфактура. Под домашним производством понимается изготовление изделий для собственных 
потребностей семьи. Под ремесленным - производство изделий по заказу потребителя. Под кустарным - изготовление изделий для сбыта на рынок неизвестному потребителю.

В 1890 г. в Барнаульском округе пимокатным производством занималось 1122 семей. По оценке А.П. Голубева, «промысел этот не замыкается в узком круге специалистов-мастеров, а делается чуть ли не обыденным домашним занятием каждого» $[1$, с. 96]. Большинство пимокатов удовлетворяли потребности в пимах своих семей и своих односельчан, не выходя за рамки домашнего и ремесленного производства. Ремесленники, как правило, начинали работать с осени - времени стрижки овец, так как на изготовление войлочной обуви шла осенняя шерсть. Мастера работали с сырьем заказчика и могли выкатать в год до 100 пар. Ассортимент включал в себя пимы, калоши. В 1909 г. стоимость мужских пимов составляла 4 рубля 20 копеек, женских - 3 рубля, калоши, соответственно, стоили 3 рубля 60 копеек и 2 рубля 75 копеек [2, с. 20]. Общий заработок пимоката достигал 100 рублей.

В кустарном производстве на территории Барнаульского округа (уезда) были задействованы различные категории производителей-пимокатов: пимокаты-одиночки; пимокаты, работавшие при помощи семейного подряда, наемных лиц. Пимокаты-одиночки работали стационарно или занимались отхожим пимокатным промыслом. Как правило, они могли объединяться в небольшие партии по 2-3 человека и уходить в отдаленные районы, где при неразвитости пимокатного промысла было в обилии сырье. Кустари-пимокаты переходили из избы в избу, предлагая свои услуги. Они работали на заказ, изготавливая изделия из хозяйского сырья. Полученного заработка хватало на обеспечение семьи питанием, необходимой одеждой и оплату взносов казенных податей и мирских повинностей [1, с. 97].

В 1915 г. промысел существовал в 201 селении Барнаульского уезда, в котором принимало участие 573 семьи, что составляло 2016 душ обоего пола, из них мужчин - 892 человека, женщин 540, подростков - 584. Женщины и дети были задействованы в подготовительных этапах при изготовлении пимов. Наибольшее количество пимокатов - от 10 до 16 семей - работало в селах Камень Каменской волости, Костином Логу Боровской волости, Сузун Сузунской волости и Волчихе Покровской волости [3, с. 74, 91]. Чаще всего производство пимов носило сезонный характер [1, с. 97]. Выделкой валенок и войлочных калош занимались в осенне-зимний период после окон- чания сельскохозяйственных работ. Шерсть осенней стрижки приобретали на месте, на ярмарке, в г. Барнауле или работали с сырьем заказчика.

Пимокаты с наемными рабочими (от 2 до 10 человек) выкатывали от 200 до 1800 пар общей стоимостью от 1000 до 3720 рублей. Реализация готовой продукции шла через местных жителей, жителей соседних селений, на ярмарках. Так, пимокаты с. Павловское сбывали свою продукцию в Барнауле, а к мастерам с. Тюменцевское приезжали скупщики из Томска. Основными рынками сбыта, помимо Барнаула, были город Ново-Николаевск, села Камень, Берское, Залесово, Сорокино, Сузун, Анисимовское. Видовой ряд выпускаемой продукции был широк: пимы, пимные колоши, чулки, чесанки, разная валяная обувь. Стоимость изделий варьировалась от 3 до 3,5 рублей за мужскую пару, 2 рубля за женскую и от 1 до 1,5 рублей за детскую. Средний заработок пимокатов составлял 268 рублей. Хотя колебания могли достигать от 25 до 3750 рублей. Годовая сумма производства варьировалась от 500 до 9010 рублей. Наибольшие показатели демонстрировали с. Павловское, Волчиха, Бутырское, Ново-Обинцево, Чистюнька [3, с. 92-93].

Помимо сельской местности пимокатный промысел активно развивался в г. Барнауле и его окрестностях. На 1910 г. в Барнауле, Булыгинской и Борзовой заимках были зарегистрированы пимокатные мастерские барнаульских мещан А.Г. Антонова, М.Г. Воробьева, О.А. Малянова, П.Е. Смердина, И.И. Тапцырева, Е.П. Черкашина, В.Ф. Варламова, М.Е. Мельгачева, В.Д. Николаева, И.Е. Новокрещенова, крестьянина Костромской губернии Д.П. Бухалова. Производство было организовано в собственных домах владельцев промысла [23, л. 1-1 об., 2 об.-3; 24, л. 2-3, 4 об., $6,8-9$ об.]. При изготовлении валяной обуви использовался ручной труд 9-14 наемных человек. Ежегодная выработка приносила прибыль в 9002400 рублей при оборотах в $10000-30000$ рублей [25, л. 51, 52-52 об., 189, 190-190 об.].

В г. Барнауле помимо кустарных заведений в конце XIX в. появились предприятия смешанной мануфактуры по производству валяной обуви. Их количество в Барнауле с 1883 по 1887 гг. выросло с 6 до 17 [1, с. 118]. По критериям Фабричной инспекции Томской губернии к фабрично-заводским предприятиям и крупным ремесленным заведениям могли относиться только те, кто имел не менее 16 наемных рабочих. К подобным заведениям податным инспектором 1 участка Барнаульского уезда были отнесены пимокатни И.И. и А.И. Поляковых, товарищества «Братья Кругло- 
вы», на которых работало в среднем от 60 до 150 человек [24, л. 5 об., 8 об.; 26, л. 147 об.-148]. Чуть меньше мастеров работало у барнаульского мещанина И.А. Малянова - от 15 до 30 человек [26, л. 147 об.-148]. Для производства валяной обуви в пимокатном заведении барнаульского мещанина А.П. Бухалова использовался труд от 15 до 50 рабочих. У братьев Ланкиных работало от 20 до 45 сотрудников. Подготовка шерсти и валяние пимов в подобных заведениях осуществлялось как в ручную, так и с применением лошадиной силы, парового и нефтяного двигателей [26, л. 148 об.-149]. Пимокатнями руководили либо сами владельцы, либо члены их семьи. Как правило, в архивных источниках указывалось, что производство находилось в собственном доме владельца. Так, в заявлении для промышленных предприятий в Барнаульское раскладочное присутствие А.Н. Бухалов указал, что при заведении имелось два складских помещения. Три шерсточесальные машины приводились в действие нефтяным двигателем в 18 лошадиных сил. В течение года проработавшим 20-50 мастерам была выплачена заработная плата, на которую было потрачено 15000 рублей. Выработка же составила 15000 пар пимов [27, л. 194-19 об.].

Себестоимость пары валяных сапог в 6,5 фунтов составляла 2 рубля 97 копеек, включая в себя затраты на материал (1 рубль 57 копеек), работу (1 рубль), содержание рабочих и прочие расходы (40 копеек). Себестоимость четырехфунтовых пимов определялась в 1 рубль 92 копейки, при цене материала 97 копеек, работе - 65 копеек, содержании рабочих и разных расходов - 30 копеек. Продукция сбывалась за 3 рубля 30 копеек и 2 рубля 20 копеек соответственно [22, л. 11-11 об.].

Одной из распространенных проблем предприятий по обработке животного сырья являлось его санитарное состояние. В фонде документов
Барнаульской городской думы имеется уведомление санитарного врача в городскую управу за 1912 г., в котором говорится об угрозе здоровью жителей г. Барнаула, так как в пимокатных заведениях, помимо случаев заражения сибирской язвой рабочих, могли образовываться колонии сибиреязвенных бацилл. Случаи заражения сибирской язвой наблюдались среди рабочих пимокатен, что связано с этапами работы мастеров - битьем шерсти, каткой войлока. Помещения находились в неудовлетворительном состоянии - грязные, маленькие, темные [28, л. 200 об.].

Анализ различных групп источников показал, что в Барнаульском округе (уезде) в конце XIX - начале XX века в населенных пунктах с водворенными переселенцами из европейской части России развивались различные формы пимокатного производства. Все они испытывали на себе влияние ряда факторов, которые либо тормозили, либо способствовали росту производства. Как показывают архивные источники, сословный состав владельцев и мастеров был неоднороден. Среди них преобладали крестьяне и мещане из европейской части России, купцы. Промысел в сельской местности в большей степени носил сезонный характер и являлся дополнительным источником доходов к занятию сельским хозяйством. Мануфактуры смешанного типа в Барнауле позволяли заниматься пимокатным делом в течение всего года. Техническое оснащение различалось в зависимости от формы производства. Модернизация трудового процесса была характерна лишь для крупных заведений. Реализация товара производилась пимокатами самостоятельно или через посредничество скупщиков на территории своего населенного пункта, развозом по близлежащим районам, на базарах, ярмарках. Лишь небольшая часть отправлялась за пределы волости или уезда.

\section{Библиографический список}

1. Алтай. Историко-статистический сборник по вопросам экономического и гражданского развития Алтайского горного округа / под ред. П. А. Голубева. Томск, 1890. 436 с.

2. Кустарные промыслы Томской губернии / сост. членами стат. семинарии под ред. М. Н. Соболева. СПб., 1909.

3. Материалы анкетного обследования кустарно-ремесленной промышленности в Томской губернии / Томский губернский кустарный комитет. Томск, 1915. 193 с.

4. Чудновский С. Л. Переселенческое дело на Алтае (Статистико-экономический очерк). Иркутск, 1889. C. $147-149$.

5. Бочанова Г. А. Обрабатывающая промышленность Западной Сибири. Конец XIX - начало XX в. Новосибирск: Наука, 1978. 254 с.

6. Соловьева Е. И. Крестьянская промышленность Сибири во второй половине XIX в. Новосибирск, 1975. 196 c. 
7. Соловьева Е. И. Промыслы сибирского крестьянства в пореформенный период. Новосибирск, 1981. 327 с.: ил.

8. Скубневский В. А. Рабочие обрабатывающей промышленности Сибири (90-е гг. XIX в. - февраль 1917 г.). Томск, 1991. 282 с.

9. Скубневский В. А. Промышленность и рабочие во второй половине XIX века // История Алтая: учебное пособие. Барнаул, 1995. Ч. І. С. 181-197.

10. Скубневский В. А. Промышленность и рабочие в конце XIX - начале XX века // История Алтая: учебное пособие. Барнаул, 1995. Ч. 1. С. 239-256.

11. Осадчий А. Н. К вопросу об особенностях технологии производства обрабатывающих промыслов Алтая в XIX в. // Этнография Алтая и сопредельных территорий. Барнаул, 1998. С. 232-233.

12. Осадчий А. Н. К вопросу о развитии обрабатывающего производства в Колывано-Воскресенском (Алтайском) горном округе в XIX в. // Актуальные вопросы истории Сибири. Барнаул, 1998. С. 138-142.

13. Осадчий А. Н. Некоторые вопросы историографии обрабатывающего производства на Алтае XIX века // Вопросы историографии, истории и археологии. Барнаул, 1996. С. 20-23.

14. Осадчий А. Н. Распространение пимокатного производства на Алтае во второй половине XIX века // Историческое краеведение: теория и практика. Барнаул, 1996. С. 180-182.

15. Скубневский В. А., Старцев А. В., Гончаров Ю. М. Купечество Алтая второй половины XIX - начала XX вв. Барнаул, 2001. 241 с.

16. Фурсова Е. Ф. Традиционная одежда русских крестьян-старожилов Верхнего Приобья (конец XIX - начало XX вв.). Новосибирск, 1997. 152 с.

17. Фурсова Е. Ф. Традиционная одежда русского и других восточнославянских народов юга Западной Сибири (конец XIX - первая треть XX века). Новосибирск, 2015. 296 с.

18. Октябрьская И. В. Пимокаты Алтая // Археология, этнография и антропология Евразии. 2009. № 4 (40). C. $120-124$

19. Шелегина О. Н. Очерки материальной культуры русских крестьян Западной Сибири (XVIII - первая половина XIX в.). Новосибирск, 1992. 252 с.

20. Мамонтова О. С. Изучение и музеефикация традиционных занятий русских Алтая в Алтайском государственном краеведческом музее // Рябининские чтения - 2015. Петрозаводск, 2015. С. 586-588.

21. Мамонтова О. С. Пимокатное производство Алтая XX в. в собрании Алтайского государственного краеведческого музея // Труды Алтайского государственного краеведческого музея. Барнаул, 2013. T. IV. C. 110-122.

22. Журналы 1-го Барнаульского Уездного по промысловому налогу присутствия за 1910 г. об определении процентов средней прибыльности торговых и промышленных предприятий г. Барнаула, имеющих торговые книги // ГААК. Ф. 52. Оп. 1. Д. 5.

23. Алфавитный список владельцев промышленных предприятий города Барнаула за 1910 год // ГААК. Ф. 52. Оп. 1. Д. 10.

24. Алфавитный список владельцев промышленных предприятий города Барнаула за 1911 год // ГААК. Ф. 52. Оп. 1. Д. 18.

25. Книга. Часть I с № 1 по 150 торговых и промышленных предприятий по 1-му Барнаульскому участку за 1913 год // ГААК. Ф. 52. Оп. 1. Д. 21.

26. Письмо Податного инспектора 1-го Барнаульского участка Томской губернии от 14 января 1914 г. № 33 // ГААК. Ф. 52. Оп. 1. Д. 20.

27. Книга. Часть I с № 1 по 390 торгово-промышленных предприятий по 1-му Барнаульскому участку за 1914 год // ГААК. Ф. 52. Оп. 1. Д. 36.

28. Технико-санитарный отдел // ГААК. Ф. 51. Оп.1. Д. 9. Л. 200 об. 